\title{
ONTOLOGIA PRZYPADLOŚCI „JAK GDYBY” W TEORII HELENY DEUTSCH: NARODZINY TEORII KOBIET ALBO SONDOWANIE GRANIC PSYCHOANALIZY
}

\author{
AGNIESZKA WIECCKIEWICZ
}

\begin{abstract}
Abstrakt: Publikowany tekst jest propozycją nowego spojrzenia na teorię Heleny Deutsch, polskiej psychoanalityczki, jednej z najbliższych współpracownic Zygmunta Freuda oraz prekursorki badań nad psychologia kobiet. Wyjście od społeczno-kulturowej historii psychoanalizy umożliwi mi ponowne przyjrzenie się obecności i znaczeniu psychoanalityczek w ruchu freudowskim. W artykule rezygnuję z utartych sposobów ujmowania freudyzmu jako wrogiego emancypacji kobiet, na rzecz badania psychoanalizy w kontekście jej narodzin i funkcjonowania w okresie do wybuchu drugiej wojny światowej. Bardziej niż miejsce Deutsch w długiej tradycji psychoanalizy kobiet, interesuje mnie autorskie i rewelatorskie ujęcie kobiecego podmiotu jako osobowości ,jak gdyby” zaproponowane przez polską lekarkę. Dowodzę, że Deutsch wpisywała się nie tylko w tradycję kobiet analityczek, skoncentrowanych głównie na praktyce klinicznej, lecz również — podobnie jak Freud w swych pracach łączyła refleksję medyczną z literaturą i filozofią. (Re)lektura jej prac w świetle filozofii plastyczności Catherine Malabou stanowi propozycję a zarazem przyczynek do badania teorii Deutsch przez pryzmat kategorii podmiotowości, pamięci i plastyczności.
\end{abstract}

Słowa kluczowe: psychoanaliza, plastyczność, Deutsch, Malabou, autoanaliza. 
Pojęcie plastyczności w filozofii pojawia się na długo przed refleksją Catherine Malabou, lecz to właśnie w jej publikacjach zyskuje ono nowe znaczenia. Wychodząc od heglowskiego rozumienia plastyczności jako zdolności podmiotu zarówno do przyjęcia, jak i donacji formy, autorka ta rozwinęła koncepcję podmiotowości jako zawieszonej między płynnością a stałością, otwartością na zmianę a oporem (Malabou 1996). W pracy Que faire de notre cerveau filozofka badała ludzką psychikę, wykorzystując w swej refleksji dyskurs filozoficzny, psychoanalityczny oraz neurobiologiczny (Malabou 2004). Plastyczność opisała wówczas jako wielość sposóbów organizacji systemowej mózgu umożliwiającą ujęcie podmiotowości w kategoriach linearnego stawania się oraz zdolności podmiotu do mniej lub bardziej trwałych przekształceń (Malabou 2016b). Z kolei ujmowana przez nią plastyczność destrukcyjna - trwałe zniekształcenie czy zaburzenie psychicznej równowagi podmiotu nie tylko nie mieści się w konotowanej pozytywnie elastyczności (zdolność jednostki do metamorfozy), lecz podważa dotychczasowe rozumienie podmiotowości. Destrukcyjna plastyczność nie tylko niszczy esencję, w przeciwieństwie do elastyczności zachowującej coś z wyjściowej formy podmiotu, ale jest też przygodna. Przypadkowa destrukcja „ja” jest stała przypadłością każdego człowieka. Koncepcje plastyczności negatywnej Malabou rozwinęła w eseju filozoficznym Ontologia praypadtości: Esej o plastyczności destrukcyjnej (Malabou 2017). $\mathrm{Na}$ czym polega jednak rozwijana przez filozofkę fenomenologia plastyczności destrukcyjnej?

Ontologia praypadtości Malabou jest traktatem o „absolutnej improwizacji egzystencjalnej" (Malabou 2017, 8). Opowiada o zawartym w każdym podmiocie potencjale do przekształcenia samego/samą siebie, stania się kimś innym. Nie chodzi tu jednak o zwyczajną metamorfozę, lecz trwałe przekształcenie, które prowadzi do nieodwracalnego uszkodzenia podmiotu oraz ukształtowania całkowicie nowej tożsamości. Francuska filozofka wprowadza w tym kontekście rozróżnienie na elastyczność i plastyczność przynależne każdej jednostce. Podczas gdy elastyczność określa ruchliwość podmiotu, jego zdolność do krótkotrwałych zmian i odchyleń, destrukcyjna plastyczność jest negatywną pracą wyniszczenia podmiotowości. Nie tylko stanowi ona część każdej możliwej konstrukcji psychicznej, lecz zarazem nadaje nowa, nieoczekiwana formę danemu życiu. Tym, co interesuje Malabou, nie jest zdefiniowanie pozytywnej plastyczności mózgu, rozumianej jako zdolność do kreatywności, lecz znalezienie języka na opisanie zjawiska destrukcji prowadzącej do wykształcenia nowej, radykalnie różnej podmiotowości. Destrukcyjna plastyczność mózgu, która jest ontologiczną przypadłością każdego podmiotu, nie została zdaniem filozofki - dotychczas opisana.

Malabou stwierdza, że „w psychoanalizie, jak i neurologii mózg plastyczny i plastyczna psyche to mózg i psyche, które odnajdują właściwa drogę między zdolnością do zmiany i podatnością na pozostanie tym samym, między przyszłością i pamięcią, między recepcją i donacja formy" (Malabou 2017, 13). Tym, co według Malabou zostaje nazwane, 
jest właśnie wyjątkowa dyspozycja podmiotu do elastyczności - czyli nietrwałych przekształceń, odgięć i odchyleń, które wzbogacają tożsamość, nie dokonując jej zniszczenia. Zupełnie inaczej jest jednak:

\begin{abstract}
z możliwością eksplozji, unicestwienia tej równowagi, możliwością destrukcji tej zdolności, tej formy, tej siły, destrukcji tożsamości w ogóle. [...] Wybuchowa, destrukcyjna i dezorganizująca moc potencjalnie wszakże obecna w każdym z nas, w każdej chwili zdolna się objawić, zmaterializować albo zaktualizować, nigdy dotąd na żadnym polu nie otrzymała nazwy (Malabou 2017, 13).
\end{abstract}

Wybuchowa i dezorganizująca moc, o której pisze filozofka, nie pojawia się ani we współczesnej, ani w klasycznej psychoanalizie. Malabou podjęła polemikę z teorią Zygmunta Freuda w swej wcześniejszej pracy, Les nouveaux blessés, poświęconej formom posttraumatycznej podświadomości (Malabou 2007). Zauważyła tam, że psychoanaliza nie znalazła języka na opisanie uszkodzeń mózgu pojawiających się u chorych na Alzheimera, Parkinsona czy pacjentów cierpiących na stres pourazowy (Malabou 2016a). Psychiczny wymiar ich życia nie daje się opisać w kontekście walki Erosa z Tanatosem. Freudowski popęd śmierci jako dążenie ku destrukcji w żadnym razie nie może być utożsamiany z plastyczną destrukcyjnością.

Krytykę psychoanalizy Malabou kontynuuje w Ontologii prasppadtości, gdzie odnosi się do freudowskiego ujęcia podmiotowości opartego na dwóch różnych rozumieniach plastyczności. Pojęcie Plastizität w pismach ojca psychoanalizy określa zarówno plastykę psychicznego życia jednostki, jak i swoistą witalność libido (Freud 2009a, 35-36). Pierwsze charakteryzuje wszelkiego typu traumy oraz piętna, które według Freuda nie mogą zostać trwale wymazane lub zapomniane. Druga właściwość określa zdolność podmiotu do zmian obiektu obsadzeń afektywnych dzięki zachowaniu elastyczności, która chroni jednostkę przed fiksacja i zapewnia jej względną wolność. Podczas gdy dla francuskiej filozofki podmiotowość jest polem nieustannego, nielinearnego stawania-się, przerywanego nagłymi zahamowaniami oraz zerwaniami przepływów, Freudowi przypisuje ona wizję elastycznej nie zaś plastycznej - psychiki jednostki. Elastyczność umożliwia przekształcenia, które nie niszcza pierwotnej postaci ,ja”; pozwala ona na wydzielenie i odzyskanie podmiotowości przekształconej w skutek traumatycznych przeżyć i doświadczeń.

Choć Malabou zajmuje krytyczną postawę wobec psychoanalizy i w Ontologii praypadtości nieraz dyskutuje $\mathrm{z}$ twierdzeniami Freuda, zauważa zarazem, że przemyślenie kategorii destrukcyjnej plastyczności czyni możliwym dialog między klasyczną psychoanalizą a współczesną neurobiologia (Malabou 2017, 52). Na czym ów dialog mógłby się oprzeć? 
W swej krytyce filozofka odnosi się zarówno do teorii psychoanalitycznej, jak i do praktyki terapeutycznej; postuluje przekształcenie języka filozofii dzięki wprowadzeniu w jego pole destrukcyjnej plastyczności, co pociagnie za sobą również zmianę podejścia lekarzy (psychiatrów, terapeutów, psychoanalityków) do pacjentów. Idąc tropami wyznaczonymi przez filozofkę, w artykule proponuje refleksję nad pojęciem destrukcyjnej plastyczności, której śladów szukam w teorii uczniów Freuda, a dokładnie w pracach jego pierwszych współpracownic. Wykażę, że wraz z pojawieniem się w polu psychoanalitycznym teorii tworzonej przez kobiety-analityczki kategoria destrukcji jako negatywnej siły unicestwienia „ja” ujawniła się w postulowanej przez niektóre z nich koncepcji nielinearnej, „migotliwej” podmiotowości.

Zmiany osobowości u pacjentek cierpiących na depresję, kobiet doświadczających wykluczenia, a jednocześnie szukających dla siebie i innych możliwych dróg wyzwolenia z okowów patriarchalnego społeczeństwa fascynowały Helenę Deutsch, polską psychoanalityczkę pochodzenia żydowskiego. W artykule przyglądam się wybranym pracom tej jednej z najbliższych uczennic i współpracownic Freuda, które umieszczam w szerszym kontekście pierwszych lat funkcjonowania Wiedeńskiego Towarzystwa Psychoanalitycznego oraz narodzin i rozwoju psychoanalizy kobiet. Co istotne, od samego początku obejmowała ona wszystkie domeny i pola działalności owego ruchu. Wraz z narodzinami psychoanalizy tworzonej przez kobiety, to pacjentki, analityczki, lekarki oraz myślicielki wypracowywały teorię oraz kształtowały praktykę psychoanalityczna. Ich aktywność miała zasadnicze znaczenie dla funkcjonowania instytucji odpowiedzialnych za rozwój psychoanalizy. W tekście pytam o to, co zmieniło się w teorii oraz samej dynamice działalności ruchu psychoanalitycznego, kiedy dołączyły do niego kobiety. Zamiast zastanawiać się nad wpływem psychoanalizy kobiet na teorię freudowską czy ich wkładem w rozwój ruchu psychoanalitycznego, przyglądam się przekształceniom zachodzacym w teorii, kiedy w jej polu pojawily się pojęcia i koncepcje proponowane przez analityczki. Wraz z narodzinami psychoanalizy kobiet rozwijane było pojęcie różnicy płciowej, kształtowały się nowe ujęcia relacji matki i dziecka oraz koncepcje matriarchatu poprzedzającego prawo ojca (Rank 2016, 309-324), a zatem idee przejęte później przez filozofki i myślicielki drugiej fali feminizmu. Dalsza część artykułu to próba (re)lektury dzieł Heleny Deutsch w świetle formułowanej przez nią teorii kobiecej seksualności oraz koncepcji osobowości ,jak gdyby”.

Przyjęta przeze mnie perspektywa wymaga jednak uczynienia kilku zastrzeżeń. Artykuły Deutsch czytam jako teksty filozoficzne, nie zaś kliniczne. Podobnie podchodzę do eseju Catherine Malabou. Na boku pozostawiam pytanie o współczesne zadania stojące przed psychoanaliza jako praktyką terapeutyczna. Z kolei w odpowiedzi na pytanie o obecność destrukcyjnej plastyczności w klasycznej psychoanalizie wychodzę od społecznokulturowego kontekstu narodzin psychoanalizy. 


\section{Ku psychoanalizie kobiet}

Elke Mühlleitner pisze o ruchu psychoanalitycznym nie tylko jako o narzędziu emancypacji kobiet, lecz postuluje wręcz, aby uznać psychoanalizę za domenę kobieca, przeznaczona i rozwijaną przede wszystkim przez pacjentki i analityczki (Mühlleitner 1999). Choć pierwsza kobieta (Margarethe Hilferding) została przyjęta do Wiedeńskiego Towarzystwa Psychoanalitycznego dopiero w 1910 roku, już wcześniej wokół Freuda gromadziły się lekarki i kobiety zainteresowane psychoanaliza. Należała do nich między innymi Ludwika Karpińska, posługująca się pseudonimem Louise von Karpinska i wprowadzona w środowisko psychoanalityków przez Ludwika Jekelsa - pierwszego polskiego freudystę (Mühlleitner 1999, 36). Z kolei Nancy J. Chodorow proponuje, aby na pierwsze pacjentki autora Totemu $i$ tabu patrzeć nie tylko jak na bierne przedmioty (i ofiary) władzy lekarza, lecz uznać je za aktywne, współpracujące z nim podmioty, które bezpośrednio wpływały na powstawanie nowej teorii i praktyki medycznej (Chodorow 1999, 11-12). Anna O., Emmy von N., Elisabeth von R. i inne pacjentki zdiagnozowane jako „histeryczne” miały decydujący wpływ na wypracowane przez Freuda techniki terapii (Freud i Breuer 2008, 46). Z kolei już w 1897 roku Emma Eckstein (słynna Irma z Objaśniania maržeń sennych) była jedną z pierwszych kobiet, która dzięki zachętom Freuda przeszła drogę prowadzącą od pacjentki do analityczki. Jej „,wejście” w pole medycyny wyprzedziło o trzy lata decyzję władz Wydziału Medycznego Uniwersytetu w Wiedniu o przyznaniu kobietom prawa do podjęcia studiów wyższych w zakresie medycyny (Mühlleitner 1999, 35-36). Począwszy od 1910 roku, liczba kobiet w Wiedeńskim Towarzystwie Psychoanalitycznym stale wzrastała. W 1911 roku do ruchu dołączyła Sabina Spielrein, która jako pierwsza kobieta zaprezentowała swój artykuł podczas jednego ze spotkań Środowego Towarzystwa Psychologicznego ${ }^{1}$ (miało to miejsce 29 listopada 1911 roku), oraz Tatiana Rosenthal. W kolejnych latach członkiniami zostały między innymi: Hermine Hug-Hellmuth (1913), Eugenia Sokolnicka (1916), Helena Deutsch i Erzsébet Révész (1918), Frieda Teller (1920), Anna Freud (1922) i Beata Rank (1923). Znamiennym przykładem intelektualnej fascynacji Freudem ze strony myślicielek i zaangażowanych społecznie kobiet była również rosyjska pisarka i filozofka Lou Andreas-Salomé. Już w 1912 roku uczestniczyła ona w posiedzeniach Środowego Towarzystwa Psychologicznego, gdzie występowała w charakterze „wolnej słuchaczki”, niezwykle zresztą cenionej przez Freuda i zachęcanej przez niego do poświęcenia się psychoanalizie (Andreas-Salomé 1983). Do Towarzystwa została przyjęta dokładnie dziesięć lat później w 1922 roku. W 1926 roku

1 Psychologische Mittwochs-Gesellschaft (Środowe Towarzystwo Psychologiczne) powstało w 1902 roku i zrzeszało pierwszych zwolenników teorii Freuda. Początkowo do Towarzystwa należeli Wilhelm Stekel, Alfred Adler, Rudolf Reitler i Max Kahane. Spotkania dyskusyjne odbywały się na Berggasse 19 w wiedeńskim mieszkaniu ojca psychoanalizy. Od 1906 protokoły ze spotkań prowadził Otto Rank. 
kobiety stanowiły już około 26\% członków, w 1931 około 33\%, zaś w 1937 prawie połowę trzydzieści jeden kobiet na sześćdziesięciu ośmiu członków (Mühlleitner i Reichmayr 1997).

Gwałtowny wzrost zainteresowania psychoanaliza wśród kobiet wynikał z jednej strony $z$ nowatorstwa i rewolucyjności teorii wypracowywanych przez Freuda oraz jego uczniów, z drugiej był efektem braku innych możliwych ścieżek kariery dla kobiet i mężczyzn pochodzenia żydowskiego. Jak zauważa Lena Magnone:

\begin{abstract}
Z pewnością można [...] przyjać, że większość pierwszych zwolenników Freuda wiaże się z psychoanalizą dopiero wtedy, kiedy zamknięte zostały przed nimi możliwości innych dróg rozwoju naukowego i zawodowego. Żydowscy studenci medycyny kierowali się ku psychiatrii [...] przede wszystkim dlatego, że ta dziedzina, jako mniej dochodowa (psychiatrzy nie otwierali własnych gabinetów i mogli praktykować wyłącznie w szpitalach), przyciagała mniej studentów nieżydowskich, przed którymi otworem stały bardziej lukratywne specjalizacje. Wraz ze wzrostem antysemityzmu również i ta droga została jednak zamknięta, co uczyniło z psychoanalizy - dziedziny [...] funkcjonującej na obrzeżach świata medycznego, uznawanej za nienaukowa i kojarzonej wprost z żydostwem [...] - jedyną realną ścieżkę kariery (Magnone 2016a, $\mathrm{VI})$.
\end{abstract}

Popularność rasistowskich teorii w ówczesnych dyskursach medycznych, z którymi na co dzień zderzali się lekarze i lekarki pochodzenia żydowskiego, nie pozostawało bez znaczenia dla teorii psychoanalitycznej (podobnie rzecz miała się z doświadczeniem antysemityzmu, Gilman 1993). Carl Schorske stwierdza wręcz, że psychoanaliza zrodziła się w momencie, kiedy Freud nie mógł już liczyć ani na karierę uniwersytecką, ani na polityczną, co nieprzypadkowo zbiegło się w czasie ze zwycięstwem Karla Luegera - przywódcy austriackiej partii Chrześcijańsko-Społecznej i otwartego antysemity - w wyborach municypalnych w Wiedniu (Schorske 1980).

We współczesnych odczytaniach teorii freudowskiej łatwo zapomnieć o społecznopolitycznym kontekście, w którym zrodziła się psychoanaliza oraz powstawały teksty pierwszych uczennic oraz współpracownic Freuda (takich jak Deutsch). Polska psychoanalityczka nie tylko należała do pierwszego pokolenia kobiet decydujących się na wyższe wykształcenie oraz karierę zawodowa, lecz była także osobą żydowskiego pochodzenia, która na studia do Wiednia przyjechała z prowincjonalnego miasta leżącego w ówczesnej Galicji. W biografii Deutsch nakładały się doświadczenia kobiety, Żydówki oraz imigrantki, co wpływało na dynamikę jej tekstów intymistycznych i teoretycznych. Choć łatwo stracić z oczu wage doświadczenia wykluczenia, z jakim musiała się zmagać psychoanalityczka, podjęta przez nią aktywna (i afirmatywna) obserwacja innych kobiet 
oraz jej własna biografia umożliwiają taką (re)lekturę jej psychoanalitycznej teorii, w której nie ucieka się od pytań o polityczny wymiar analiz Deutsch.

\section{Feministyczna prekursorka}

Deutsch zajmuje ambiwalentne miejsce w historii feminizmu. W kontekście narastającej krytyki psychoanalizy, która była rozwijana przez filozofki i myślicielki feministyczne od lat czterdziestych ubiegłego wieku, losy i recepcja prac Deutsch nie powinny zaskakiwać. Polska psychoanalityczka od czasu publikacji swego najobszerniejszego dzieła The Psychology of Women spotykała się z nieustanną krytyką i zarzutami o antyfeminizm (Deutsch 1944/1945). Amerykańskie i francuskie feministki drugofalowe uznały ją za wierną kontynuatorkę teorii Freuda, czyli myśli przedstawianej jako patriarchalna i de facto opresywna względem kobiet.

Klasyczną psychoanalizę freudowską przywykło się traktować nie tylko jako przeciwną emancypacji kobiet, lecz także jako odpowiedzialną za wzmocnienie esencjalistycznej filozofii kobiecego podmiotu - słabego, histerycznego, wybrakowanego, biernego i pasywnego. Betty Friedan, Germaine Greer, Shulamith Firestone, Kate Millet w Stanach Zjednoczonych i Simone de Beauvoir, Luce Irigaray oraz Élisabeth Badinter we Francji to tylko niektóre $\mathrm{z}$ teoretyczek feminizmu podejmujących w swoich pracach krytykę freudyzmu. Dla większości z nich punktem wyjścia do budowania własnej filozofii i teorii był sprzeciw wobec teorii psychoanalitycznej. Upatrując w psychoanalizie winy za krzywdzący i niesprawiedliwy obraz kobiety, feministki podjęły próbę dekonstrukcji konceptów, które przypisały Freudowi, jak również jego uczniom i uczennicom. Wysiłek obrony psychoanalizy dzięki wnikliwej lekturze prac Freuda podjęła Juliet Mitchell, co do dziś pozostaje jednym z nielicznych przykładów przyjęcia krytycznej postawy względem feministycznych drugofalowych odczytań freudyzmu (Mitchel 1973). Na polskim gruncie nowe i polemiczne względem wcześniejszych spojrzenie na prace Heleny Deutsch zaproponowała Lena Magnone (2016b).

W latach dwudziestych dwudziestego wieku powstała i rozwijała się teoria kobiecej seksualności zapoczątkowana przez Deutsch, której prace zmusiły Freuda do zrewidowania własnego stanowiska w kwestii seksualnego rozwoju kobiet. Autor Objaśniania marzeń sennych uczynił to w krótkim artykule Kilka psychicznych skutków anatomicznej różnicy ptci opublikowanym w 1925 roku (Freud 2009b). Wyznaczone w tym okresie nowe kierunki badań psychoanalitycznych charakteryzowały się odejściem od teorii kompleksu Edypa na rzecz 
przemyślenia i dowartościowania fazy preedypalnej - ściśle związanej z figura matki oraz relacją matka-dziecko. Lata 1924-1925 to moment radykalnych przekształceń w teorii psychoanalitycznej. Lektura prac Ottona Ranka, Sándora Ferencziego czy Beaty Rank z tego okresu okazuje się szczególnie inspirująca dla współczesnego myślenia o psychoanalizie z perspektywy feministycznej. Polemika z freudowskim Edypem pojawiła się w polu psychoanalizy na długo przed krytyką Deleuze’a i Guattariego, choć wówczas nie przerodziła się w radykalne odrzucenie trójkąta rodzinnego i redefinicję freudowskiego pragnienia.

W 1924 roku Deutsch wygłosiła referat na temat psychologicznego wymiaru biologicznego macierzyństwa („Psychologia kobiet w odniesieniu do funkcji prokreacji”, VIII Międzynarodowy Kongres Psychoanalityczny, Salzburg) (Deutsch 2016c). Już na samym początku wystąpienia badaczka podkreśliła wyjątkową trudność w procesie „dorastania infantylnego libido do normalnego heteroseksualnego wyboru obiektu” w przypadku psychoseksualnego dojrzewania kobiety (Deutsch 2016c, 327-329). Sformułowanie „,normalny heteroseksualny wybór obiektu” można rozumieć całkiem dosłownie „normalny” oznacza najczęściej występujący albo prowadzący do realizacji biologicznych uwarunkowań kobiety, w tym wypadku urodzenia dziecka. Jak dowodził Freud, postulując pierwotny biseksualizm każdego ludzkiego podmiotu, heteroseksualizm nie jest „naturalny” (automatycznie dany) w równym stopniu co „homoseksualizm”. Zarówno pierwszy, jak i drugi warunkowany jest indywidualnym rozwojem psychofizycznym jednostki oraz jest realizowany w formach, które przewidziano w społeczeństwie dla kobiet i mężczyzn.

W odczycie psychoanalityczka nie rozwinęła również wątku kobiecej „zazdrości o penisa", tak istotnego dla Freuda i całej późniejszej feministycznej krytyki jego teorii. Pisze bowiem: „Zakończeniem procesu stawania się kobietą nie jest zaspokojenie infantylnego pragnienia posiadania członka [...], lecz w pełni udane odkrycie waginy jako organu rozkoszy - zamiana zazdrości o penisa na rzeczywiste i równowartościowe posiadanie waginy" (Deutsch 2016c, 327). „Wagina” podobnie jak „penis” muszą stać się dla posiadających te organy podmiotów miniaturami całego ,ja”. Nie jest to jednak punkt wyjścia dla żadnej z płci - obie muszą przejść mniej lub bardziej trudny proces dowartościowania bądź przewartościowania własnych genitaliów na poziomie symbolicznym (Ferenczi 1924).

Na wcześniejszym etapie najważniejszym obiektem dla małej dziewczynki nie jest, jak chciał tego Freud, ojciec, lecz matka - a konkretnie jej pierś, która w pierwszej, oralnej fazie (autoerotycznej) przyjmuje funkcję aktywno-przewodniego organu rozkoszy. Matczyna 
pierś, pisze Deutsch, traktowana jest przez dziecko jako część jego własnego ciała. Dla dziewczynki w okresie „fallicznym” łechtaczka jest namiastką penisa, chociaż według psychoanalityczki brakuje jej pełnej siły męskiego narządu płciowego. Efektem tej słabości nie jest jednak, jak chciałby Freud bądź jego krytyczki, rosnąca zazdrość o penisa, lecz zwiększenie erogenności całego ciała kobiety. Doniosłym odkryciem Deutsch w omawianym okresie było z jednej strony wskazanie na mechanizm utożsamienia kobiety z matką w trakcie stosunku, zarówno heteroseksualnego, jak i homoseksualnego, z drugiej wskazanie na proces stawania-się matką rozumiany jako droga przezwyciężenia traumy narodzin.

Twierdzenie polskiej psychoanalityczki o porodzie jako „orgii masochistycznej przyjemności” ściągnęło na nią największą krytykę autorek feministycznych. Warto przyjrzeć się większemu fragmentowi tekstu, w którym rozwija ona owo sformułowanie:

\begin{abstract}
U wielu gatunków zwierząt, na przykład u niektórych pająków, samica ginie po wypełnieniu funkcji rozmnażania. Jeśli wyzwolenie popędu śmierci jest następstwem zaspokojenia seksualnych dążeń, można chyba założyć, że szczytowym punktem tego zaspokojenia jest dla kobiety akt rodzenia. W rzeczywistości okazuje się, że poród jest dla kobiety orgią masochistycznej przyjemności, a poprzedzające ten akt lęk oraz przeczucie śmierci wyraźnie odpowiadaja postrzeganiu groźby wyzwolonego popędu śmierci (Deutsch 2016c, 334).
\end{abstract}

Według Deutsch poród, a zatem i cały okres ciąży, wiąże się najpierw z pobudzeniem, następnie zaś z wyzwoleniem popędu śmierci. Pierwszy gest psychoanalityczki polega na uznaniu ciąży za symboliczną kontynuację aktu seksualnego. Poród określiła zaś jako zwieńczenie seksualnych dążeń podmiotu, w następstwie których pobudzone i wyzwolone zostaje pragnienie destrukcji. Kiedy Deutsch pisze o masochistycznej orgii przyjemności, nie odnosi się do seksualnej przyjemności, lecz raczej do jej wybuchowego wymiaru ściśle powiązanego z popędem śmierci - nieopanowanego pragnienia unicestwienia poddającego podmiot metamorfozie i rekonfiguracji. W tej optyce poród jest niesprowadzalny do aktu seksualnego rozumianego jako krótkie zdarzenie między dwoma partnerami, lecz pojmowany jest znacznie szerzej - stanowi droge rozwoju i dojrzewania kobiecego podmiotu rozpoczynającą się wraz z narodzinami, a kończącą w momencie śmierci. 
Dla autorki The Psychology of Women ciąża zyskiwała dla kobiety symboliczną formę regresji do łona matki - powrotu do samych początków - aktu, który według teorii Sándora Ferencziego określał pierwotną oraz podstawowa potrzebę każdej żywej istoty (Ferenczi 1924).

\section{Autoanalityczne i autobiograficzne przepływy}

Podobnie jak w przypadku wielu psychoanalityków tak też u autorki The Psychology of Women granica między tekstami teoretycznymi a autobiograficznymi pozostaje niewyraźna, zaś samo pisarstwo Deutsch można traktować jako przykład nieustannego oscylowania między tym, co osobiste a tym, co teoretyczne (postrzegane jako naukowe i obiektywne). Jej autobiografia, wydana w języku polskim pod tytułem Konfrontacja z sama soba: Epilog, jest zarówno studium autokreacji, mechanizmów tworzenia obrazów samej siebie, jak i przykładem autoanalizy podjęcia szczerej próby opowiedzenia o sobie, wpisania własnej historii w ramy spójnej, linearnej narracji. Deutsch nie poświęciła tam wiele miejsca macierzyństwu, stwierdziła jednak we wstępie, że „dopiero po ukończeniu tej autobiografii zdałam sobie sprawę, że jest ona swego rodzaju suplementem do właściwej autobiografii, którą skrywa moja najważniejsza praca The Psychology of Women" (Deutsch 2008, 9). Deutsch poświęciła macierzyństwu (także własnemu) cały opasły tom swego opus magnum, gdzie pod niejednym opisanym przypadkiem kryły się jej własne doświadczenia (Magnone 2016b, 523-525).

Dzięki konfrontacji ze wspomnianą wyżej autobiografią doświadczenie i historię polskiej psychoanalityczki odnajdujemy w opisie przypadku pani Smith, który na tyle zainteresował Simone de Beauvoir, że przywołała go w rozdziale poświęconym macierzyństwu oraz matkom w Drugiej płci (Beauvoir 2014, 578-579). Jak wiele innych kobiet pani Smith nie była wolna od obaw przed nieszczęśliwym porodem i wizji śmierci dziecka. Istotnie, pierwsza ciąża zakończyła się w jej przypadku poronieniem. Za kolejnym razem kobieta urodziła już zdrowe dziecko. Stało się tak zdaniem Deutsch przede wszystkim dzięki zażyłości z przyjaciółka, która również w owym czasie spodziewała się dziecka. W opisie przypadku pani Smith szczególnie podkreślony został charakter relacji matki z córka - jeśli matka była zimna i nieczuła to nie należy się dziwić, że właśnie w trakcie ciąży powraca zadawniona nienawiść i żal do niej, przeszkadzając bądź wręcz uniemożliwiając kobiecie stanie się matka. W Konfrontacï z sama sobq... Deutsch wspomina własny kontakt z matka chłodna, wymagająca, dbającą o zachowanie pozorów zgodnie z mieszczańską moralnością 
końca dziewiętnastego wieku. Tak jak w przypadku pani Smith matka Heleny oczekiwała chłopca, a urodzenie dziewczynki traktowała jako prawdziwy zawód. Deutsch wspomina również jej brutalność. Wypierana przez lata złość powróciła, gdy psychoanalityczka była w ciąży. Następujący fragment to niemalże wierne powtórzenie historii pani Smith przywołanej przez de Beauvoir:

Zaszła w ciążę po raz drugi, ale obawiała się, że znów nastąpi jakiś wypadek. Na szczęście jej serdeczna przyjaciółka była w ciąży w tym samym czasie. Ta przyjaciółka miała czuła matkę, która opiekowała się obydwiema młodymi kobietami w czasie ciąży. [...] Ku wielkiemu zdziwieniu otoczenia przyjaciółka pozostawała w ciąży o miesiąc dłużej, niż przewidywała, i obie urodziły jednego dnia (Beauvoir 2014, 578-589).

U Deutsch zmieniła się jedynie bohaterka:

Jeszcze przed poczęciem bałam się, że nigdy nie będę miała dzieci, i ten lęk nie opuścił mnie podczas ciaży. Nie potrafiłam uwierzyć, że moja [...] ciąża zakończy się urodzeniem dziecka. W tych lękach nie było nic nadzwyczajnego. [...] Żywiłam także pogodne i przepojone radościa nadzieje, lecz były one zmieszane panika, jak gdyby dawno pogrzebane we mnie siły wciąż miały moc destrukcji (Deutsch 2008, 137).

Chociaż w powyższym fragmencie psychoanalityczka zrezygnowała z języka psychoanalizy, moc destrukcji oznacza pobudzony w okresie ciąży popęd śmierci, który dla kobiety czyni z tego okresu nieustanne pole walki rozgrywające się wewnątrz podmiotu. $\mathrm{Na}$ szczęście w donoszeniu ciąży „pomogła” Helenie jej przyjaciółka. Stała się ona dla autorki Konfrontacji z sama sobq obiektem przeniesienia uczuć kierowanych pierwotnie na matkę oraz wpłynęła na ich przeobrażenie:

Moja przyjaciółka [...] zaszła w ciążę na miesiąc przede mną i dzięki identyfikacji z nią mój wzorzec macierzyństwa uległ przeobrażeniu. Poprzez psychologiczne pobudzenie sił biologii moje pragnienie dziecka zostało zaspokojone, a przyjaciółka urodziła synka miesiąc po terminie - właśnie wtedy nadszedł mój czas (Deutsch 2008, 137-138). 
Dalsze losy pani Smith i Heleny Deutsch rozchodzą się - pierwsza po raz kolejny zaszła w ciążę, która zakończyła się poronieniem, jak tłumaczy analityczka ze względu na wyjazd przyjaciółki, druga urodziła syna. Bez wątpienia w The Psychology of Women kryje się o wiele więcej takich fragmentów. Wpisując własną biografię w historie poszczególnych przypadków, Deutsch podważyła prostą opozycję między tekstem naukowym (kliniczny opis przypadku) a esejem o charakterze intymistycznym; stworzyła tym samym prace spajające elementy pisarstwa naukowego (opartego na empirii), teoretycznego (refleksyjnego), intymistycznego (autobiograficznego) oraz fikcjonalnego, wskazując przy tym na ich wzajemne powiązania.

W Konfrontacji z sama soba Deutsch nieraz odwoływała się do twierdzeń z The Psychology of Women oraz podkreślała ich autobiograficzną podstawę. Zajmując się problemem łączenia zawodowych i rodzinnych ambicji kobiet czy modelem wychowania dzieci, Deutsch nie budowała teorii oderwanych od doświadczenia kobiet. Za jej mniej lub bardziej trudnymi do przyjęcia koncepcjami teoretycznymi stały przeżywane przez nią samą konflikty oraz autoanalityczna próba wyjaśnienia trudności, z jakimi zmagała się przez całe życie. W tym świetle analiza innego, próba zrozumienia pacjentki nigdy nie pozostawała oderwana od procesu introspekcji. Obszar teorii (tego, co publiczne) funkcjonuje w jej tekstach w ciagłym napięciu i relacji do biografii (tego, co prywatne), a granica dzieląca podmiot badający od przedmiotu badań znika. Deutsch proponowała traktować Konfrontacje z sama soba jako epilog do jej właściwej autobiografii - The Psychology of Women. Choć autobiografia nie powinna być traktowana jako wynik autoanalizy (ta druga w odróżnieniu od tej pierwszej bazuje na wolnych skojarzeniach), to proces spisywania wspomnień, nadawania przeżytemu życiu ciąłości i linearności ujawnił ich wzajemną bliskość:

Pisanie autobiografii to proces podlegający znacznie silniejszej kontroli niż analityczna metoda wolnych skojarzeń. Dlatego też zdumiewam się, jak często wspomnienia, od dawna uważane przeze mnie za pogrzebane poza obszarem świadomości [...] powracały bez specjalnych oporów, podczas pracy nad autobiografia (Deutsch 2008, 13).

Ostatecznie literacki gatunek autobiograficzny wymusza autoanalityczna prace pamięci, tak jak tekst naukowy (The Psychology of Women) pozostaje w ścisłym związku z Konfrontacja z sama soba. W przedmowie do pierwszego wydania autobiografii Deutsch pisze: „Dopiero 
po ukończeniu tej autobiografii zdałam sobie sprawę, że jest ona swego rodzaju suplementem do właściwej autobiografii, którą skrywa moja najważniejsza praca The Psychology of Women. Właśnie dlatego postanowiłam nadać tej książce [autobiografii - przyp. AW] podtytuł »Epilog«" (Deutsch 2008, 9). To zasadnicze zatarcie granic między tekstem naukowym, domyślnie uznawanym za obiektywny, a prywatnym, opartym na własnym i jednostkowym doświadczeniu, umożliwia jednoczesną lekturę tekstów polskiej psychoanalityczki jako prac naukowych oraz literatury dokumentu osobistego, na co wskazała Magnone (2016b, 441). Ich naukowa wartość nie zostaje tutaj w żaden sposób podważona. Przeciwnie, taki tryb lektury służy śledzeniu napięć i wzajemnych przepływów między tym, co naukowe a tym, co osobiste i prywatne.

\section{Próby zapisu i praca pamięci}

„Pamiętniki starszej osoby powstają pod wyraźnym wpływem uwarunkowań psychobiologicznych, które dla każdej jednostki są niemal identyczne (Deutsch 2008, 11)" pisze Deutsch w Konfrontacji z samq sobq. Kiedy jej praca ukazała się po raz pierwszy, psychoanalityczka miała osiemdziesiąt dziewięć lat. We wstępie zwróciła szczególną uwagę na starość - okres osłabienia impulsów seksualnych oraz zbliżającej się śmierci. Według Deutsch starszy człowiek musi walczyć o ocalenie „kurczącego się poczucia własnej tożsamości” przed zbliżającymi się i najczęściej nieuniknionymi psychicznymi zniekształceniami (Deutsch 2008, 12). Pisząc to we wstępie do własnej autobiografii, zdawała się sugerować, że groźba destrukcji własnego ,ja”, widmo stania się sobie obcym w „wyniku poważnych psychicznych przekształceń” - trwałej zmiany - było jej własną obawa.

W Ontologii praypadtości Catherine Malabou rozróżniła dwa typy podejścia do starości: raz ujmowała ja jako utratę plastyczności, innym razem jako manifestację destrukcyjnej plastyczności niszczącej podmiot. Pierwsza koncepcja została oparta na uznaniu starości za naturalny proces, który stanowi nieuniknione zwieńczenie życia jednostki charakteryzujące się pasywnością oraz wycofaniem z aktywnego życia. W drugiej zdefiniowała starość jako zdarzenie wdzierające się w życie przypadkowo, bez żadnego zrozumiałego uzasadnienia. Za Gérardem Le Gouèsem Malabou wprowadza jeszcze trzecią możliwość - jest nią powolne, procesualne starzenie się, które ujęła jako „stawanie-się-starym” (Malabou 2017, 68). Kiedy Deutsch pisała, że „często widzimy, jak starzejący się człowiek zmaga się z postępującym niedołężnieniem, usiłując bronić się udawaniem, że nic się nie dzieje, [...] jak 
upiększa przeszłość, żeby w końcu znaleźć odrobinę pociechy w dumnym słowie »byłem«" (Deutsch 2008, 12), bliska była teleologicznemu ujęciu starości pojętej jako naturalny proces biologiczny, któremu jednostka opiera się dzięki wspomnieniom. Owe zachowane resztki ,ja” zostają uaktywnione dzięki i wskutek pracy pamięci. Polska psychoanalityczka dodaje jednak, że: „Wielkim osiagnnięciem ducha jest akceptacja teraźniejszości bez złudzeń, [...] przy jednoczesnym zachowaniu tych wartości, które nam jeszcze pozostały" (Deutsch 2008, 12). Przytoczony fragment można odczytać jako zadeklarowanie szczerości przez autorkę przeszłość ma być tutaj traktowana bez upiększania. Z drugiej strony wysiłek, jakim jest dla ducha akceptacja teraźniejszości, utrzymanie tych resztek wartości, które dają się jeszcze zatrzymać, świadczy o rozbiciu integralności doświadczanym przez podmiot. Dopiero widmo destrukcyjnej wybuchowości rozsadzającej „ja” wzmacnia radość z wypowiedzenia hasła „byłam”. Polska psychoanalityczka skłania się jednak ku trzeciej drodze proponowanej współcześnie przez Malabou - stawaniu-się-starym. Francuska filozofka tłumaczy ten proces następująco: „zgodnie ze schematem stawania-się-starym bycie plastycznym polega na umiejętności stopniowego nadawania formy schyłkowi, na wynajdywaniu niejako swej własnej starości, na umiejętności »radzenia sobie« i »pozostawania młodym«" (Malabou 2017, 70). Zapisując własną historię, Deutsch zachowała pojęcie pozytywnej (niedestrukcyjnej) plastyczności „ja”, która umożliwiła jej samej swobodne przemieszczanie się między tym, czym „była” kiedyś, a tym, czym ,jest” w momencie pisania.

Feministyczna autorka Leigh Gilmore stwierdza, że podmiot autobiograficzny nie istnieje przed tekstem, lecz kształtuje się dopiero w zapisie (Gilmore 1994, 59). Za amerykańską badaczką można powiedzieć, że spisująca autobiografię Deutsch stworzyła się na nowo (por. Magnone 2016a, 452-453). W proponowanej przeze mnie lekturze prac Deutsch odchodzę od poststrukturalistycznego podejścia do prac z zakresu szeroko pojętej intymistyki. Pisanie autobiografii traktuję raczej jako czytelny gest nadania swojej biografii ciagłości, umieszczenia jej w ramie linearnie rozwijającej się historii przez podmiot określony nie tylko przez tekst, lecz i doświadczenie. Autorka The Psychology of Women była w pełni świadoma tej pierwotnej nielinearności i niespójności podmiotu, nadając swojej autobiografii tytuł Confrontations with Myself. Chodzi tu zatem nie o konfrontację w liczbie pojedynczej, lecz o szereg konfrontacji, które wymagaja nieustannego powielania oraz odnawiania. Już w przywołanym przykładzie ujawnia się dwudzielna struktura podmiotowości postulowana przez Deutsch - „ja” konfrontuje się z „ja”, ale nie raz, a wielokrotnie. Wskazuje to na 
zakładana przez analityczkę migotliwość oraz nieuchwytność podmiotu wymykającego się poznaniu w procesie introspekcji.

\section{Tożsamość w ucieczce}

W 1934 roku na posiedzeniu Wiedeńskiego Towarzystwa Psychoanalitycznego polska badaczka wygłosiła referat Über einen Typus der Pseudoaffektivität (,„Als ob”) dotyczący pewnego szczególnego typu podmiotowości określonego terminem „jak gdyby”. Kobiece osobowości tego typu wykazywały się najczęściej szczególną inteligencją oraz aktywnością, efekty ich działań nie odznaczały się jednak niczym szczególnym; trudno było doszukać się w nich choćby najmniejszego śladu osobistego wkładu autorek. Ich relacje z otoczeniem z pozoru wydawały się „normalne”. W rzeczywistości cechował je brak jakiegokolwiek ciepła bądź uczucia, ponieważ: „każda wyrażona emocja istnieje tylko jako forma - tak jak w przypadku aktora, dobrze wyszkolonego technicznie, lecz działającego poza prawdziwym życiem" (Deutsch 2016b, 355). Wszelkie wewnętrzne emocje, uczucia i pragnienia osobowości „jak gdyby” zostały wyłączone. Również kontakt z rzeczywistością kobiet badanych przez Deutsch okazywał się zaburzony:

Pozornie normalna relacja ze światem pod względem treści odpowiada całkowicie dziecięcemu popędowi do naśladowania i jest wyrazem utożsamienia z otoczeniem, psychiczną mimikrą, której efektem jest skuteczne przystosowanie do świata rzeczywistości [...]. Takie przystosowanie pomimo braku przeżyć afektywnych jest właśnie tym, co nazwałam osobowością ,jak gdyby” (Deutsch 2016b, 356).

Doświadczanie i przeżywanie rzeczywistości przez osobowości „jak gdyby” odbywało się na zasadzie mimikry, nieustannego powtarzania i odtwarzania. Podobnie jak w przypadku aktora podmiotowości te były zdolne do płynnego przechodzenia od jednego typu osobowości do innego, nie związując się z żadnym z nich. Przypominały tym samym niezakorzenionych nomadów swobodnie przemieszczających się przez zróżnicowane przestrzenie i kultury, zbliżając się mocno do podmiotowości nomadycznych Rosi Braidotti (2009). Ich pasywne nastawienie do otaczającej rzeczywistości przejawiało się według Deutsch „szczególnie plastyczną gotowością do przyjęcia każdego sygnału pochodzącego 
ze świata zewnętrznego i ukształtowania się zgodnie z nim" (Deutsch 2016b, 356). Postawę zaobserwowanego typu kobiet analityczka określiła jako „pasywna plastyczność”. Miała ona polegać na zdolności podmiotu do całkowitego utożsamienia się z innymi ludźmi, przejmowania ich osobowości, a jednocześnie w żaden sposób nie wymagała zakorzeniania się w nich.

W takim ujęciu „pasywna plastyczność” nie odpowiada destrukcyjnej plastyczności Malabou, nie wpasowuje się też w definicję elastyczności czy „pozytywnej” plastyczności. Podmiotowości „jak gdyby” bliższe są pojęciu fleksybilności, cechuje je szczególna giętkość, niezakorzenione i płynność. Zachowuja one pewne elementy wyjściowej formy (Malabou 2017, 151-152). Pod „pasywna plastycznościa” rozumiem określający podmiot stan, który charakteryzuje się emocjonalnym „odcięciem” od otoczenia lub, jak ujmuje to Deutsch, „brakiem afektywnego obsadzenia obiektów” (Deutsch 2017, 356). Z kolei destrukcyjna plastyczność Malabou jest wydarzeniem, którego efektem jest zniszczenie dotychczas funkcjonującego ,ja”. Wydarzeniowość destrukcji jest przeciwieństwem długotrwałej i ciagle odtwarzającej się zdolności podmiotu do przemieszczeń, które jednocześnie nie wymagają od niego zakorzenienia się w otaczającej go rzeczywistości. „Pasywna plastyczność” nie jest długotrwałym stanem ruchliwości i oderwania, lecz raczej mechanizmem polegającym na wielokrotnym powtarzaniu wyniszczenia ,ja” (destrukcyjne wydarzenie) oraz jego późniejszym odtworzeniu (przejęcie, odegranie nowej tożsamości). Destrukcję można też rozumieć jako rozerwanie tego, co dotychczas funkcjonowało jako integralny podmiot, zaś późniejsze utożsamienie z innymi ludźmi jako proces zszywania nowego „ja” z dostępnych w otoczeniu kawałków-wzorców. Pozostaje jednak pytanie: czy ów „zerwany” podmiot ,jak gdyby” przechowuje resztki ,ja”, czy też staje się raczej kimś zupełnie obcym w efekcie wydarzenia-destrukcji całkowicie niszczącej dotychczas funkcjonujące „ja”? Jedynie w drugim wypadku pasywna plastyczność zbliżałaby się do destrukcyjnej plastyczności Malabou. Choć podmiotowości ,jak gdyby” nie zakorzeniają się w przyjmowanych kolejno formach-tożsamościach, wydaje się, że u Deutsch, podobnie jak u Freuda, seria przeżytych traum nie usuwa pierwotnego ,ja” podmiotu.

Warto przyjrzeć się bliżej mechanizmowi destrukcji w artykule Deutsch oraz teoretycznej propozycji zawartej w koncepcji „osobowości jak gdyby”, która jest bardzo szeroka. Polska psychoanalityczka problematyzuje bowiem nie tylko samo wydarzenie zniszczenia „ja”, lecz także cały (i daleko bardziej złożony) proces jego od-twarzania - 
wytwarzania podmiotowości, który odbywa się na zasadzie pasywnej. Zawiera on w sobie zarówno negatywny aspekt destrukcji, jak i element twórczy pozwalający na owo odtworzenie. W istocie podobny mechanizm zachodzi u Malabou: destrukcja, definitywne przerwanie historii jednostki pociaga za sobą przyjęcie kolejnej formy, nowej postaci. Filozofka pisze: „Jedynym innym, jaki wówczas istnieje, jest bycie innym wobec samego siebie" (Malabou 2017, 50). Łudząco przypomina to twierdzenie Deutsch, która tłumacząc emocjonalny chłód pacjentek z osobowością ,jak gdyby”, zauważyła, że ich problem nie polegał na wyparciu, lecz na rzeczywistej utracie zdolności do życia afektywnego (Deutsch 2016b, 356). Pozostając sobie nieznanymi, nie nawiązywały one uczuciowych relacji z otoczeniem. Zarówno w pierwszym, jak i drugim przykładzie „coś” z pierwotnej formy podmiotu zostaje zachowane, skoro ostatecznie pacjenci stają się innymi dla samych siebie. To co zbliża propozycje Malabou i Deutsch, to założenie o szukaniu możliwych dróg ucieczki przez cierpiące podmioty. Osobowość ,jak gdyby” z cała pewnością opisać można jako „tożsamość uciekająca”, której definicję francuska filozofka przedstawiła w Ontologii praypadtości: „Metamorfoza przez destrukcję nie jest ekwiwalentem ucieczki; jest raczej forma, jaką przyjmuje niemożliwość ucieczki” (Malabou 2017, 22). Jeśli pomyśleć sytuację ekstremalnego cierpienia czy napięcia, pisze Malabou, to powstająca wówczas potrzeba ucieczki skierowana zostaje na zewnętrze, które nie istnieje. Ukształtowana w ten sposób uciekająca tożsamość „ucieka od niemożliwości ucieczki” (23). Destrukcyjna plastyczność umożliwia zatem:

zjawienie się bądź uformowanie odmienności tam, gdzie innego brak w sposób absolutny. Plastyczność jest formą odmienności tam, gdzie brakuje wszelkiej transcendencji - transcendencji ucieczki albo uniku. Jedynym innym, jaki wówczas istnieje jest bycie innym wobec siebie samego (23-24).

Pasywne podmiotowości Deutsch w swojej ucieczce również pozostają nieobecne, zawsze „jak gdyby” inne, ,jak gdyby” obce. Koncepcja autorki The Psychology of Women łączy w sobie gwałtowne wydarzenie wyniszczenia podmiotu (eksplozję plastyczności) z długotrwałym procesem seryjnych wydarzeń wytworzenia-powtórzenia ,ja”. Sądzę, że dla uczennicy Freuda struktura podmiotowości nigdy nie była linearna, bowiem rozumiała ją ona jako zbudowaną z nakładających się na siebie warstw. Przez pryzmat odkrywanej przez podmiot 
wielowarstwowości „ja” i nielinearnej konstrukcji jego własnej podmiotowości można odczytywać rewolucyjny w swoim czasie tekst Deutsch Über weibliche Homosexualität (opublikowany w 1932 roku w Internationale Zeitschrift für Psychoanalyse, Deutsch 2016a).

Swój artykuł psychoanalityczka oparła na wnioskach z analiz prowadzonych na jedenastu homoseksualnych pacjentkach. W opozycji do Freuda od razu zaznaczyła, że jej rozmówczynie nie odznaczały się ani męskim wyglądem, ani zachowaniem - wpisywały się raczej w typ „kobiecych” kobiet. Szczególną uwage poświęciła jednej z pacjentek, której analiza nie została zakończona „pomyślnie”, choć sama zainteresowana osiagnęła cel terapii:

\begin{abstract}
Miałam nadzieję, że wraz z przywróceniem do życia relacji z ojcem, a przede wszystkim przez jej odświeżenie i poprawę libidinalna, przyszłość pacjentki stałaby się bardziej korzystna. Wysłałam ja zatem do pewnego analityka typu ojcowskiego. Niestety, przeniesienie udało się tylko na poziomie uwagi i sympatii. Po krótkim czasie pacjentka przerwała tę analizę. Mniej więcej rok później spotkałam ją i ujrzałam przed sobą kwitnąca, promieniejącą szczęściem kobietę. Opowiedziała mi, że jej stany depresyjne całkowicie zniknęły. Nostalgiczne pragnienie śmierci, które wcześniej stale odczuwała, wydawało się jej teraz odległym wspomnieniem. W końcu odnalazła swoje życiowe szczęście w nadzwyczajnie błogim i niepohamowanie seksualnym związku z pewną kobieta. Pacjentka, bardzo inteligenta i analitycznie dobrze obeznana, dostarczyła mi objaśnienia, że jej homoseksualna relacja rozgrywa się w całkowicie świadomej formie matka-dziecko, przy czym raz jedna, a innym razem druga kobieta odgrywa rolę matki, bawiąc się, że tak powiem w podwójne obsadzenie ról. [...] Nie można było dostrzec w tej relacji opozycji ról „męska-żeńska”; istotny był kontrast między aktywnością a pasywnością. [...] uszczęśliwienie wynikało z możliwości odgrywania obu ról (Deutsch 2016a, 345).
\end{abstract}

Jak zwraca uwagę Deutsch, to pacjentka naprowadziła ją na kluczową kwestię świadomego odgrywania ról matki i dziecka w relacji homoseksualnej. Swobodna zabawa owymi rolami na płaszczyźnie psychicznej dała kobietom możliwość jednoczesnego stania się matką i córką; wyzwoliła tym samym zawarty w podmiocie potencjał do „powielenia się” i ujawniła podwójność wyrażoną w figurze matki-dziecka.

Proponowana przeze mnie analiza z pewnością nie wyczerpuje możliwości płynących z lektury tekstów Deutsch w świetle filozofii podmiotu Malabou. Ukazuje jednak nowatorstwo koncepcji polskiej psychoanalityczki, która zestawiana i czytana była przede wszystkim w kontekście prac feministycznych myślicielek kojarzonych z druga fala 
francuskiego i amerykańskiego feminizmu. Dotychczas nie zwrócono uwagi, że nielinearna, ruchoma koncepcja podmiotowości stanowiła podstawę zarówno psychoanalitycznej teorii Deutsch, jak i jej tekstów biograficznych, w których ,ja” podmiotu zawsze pozostawało nieuchwytne, wymagało od niego pozostawania w ciąłym ruchu i prowadziło ostatecznie do nieustannie ponawianych konfrontacji z samym soba. 


\section{Wykaz literatury}

Andreas-Salomé, Lou. 1983. In der Schule bei Frend. Frankfurt am Main: Ullstein.

Beauvoir, Simone de. 2014. Druga płeć. Tłum. Gabriela Mycielska i Maria Leśniewska. Warszawa: Wydawnictwo Czarna Owca.

Badinter, Élisabeth. 1998. Historia miłości macieraynnskiej. Tłum. Krzysztof Choiński. Warszawa: Oficyna Wydawnicza Volumen.

Braidotti, Rosi. 2009. Podmioty nomadyczne: Ucieleśnienie i różnica seksualna w feminiẓmie wspótczesnym. Tłum. Aleksandra Derra. Warszawa: Wydawnictwo Akademickie i Profesjonalne.

Chodorow, Nancy J. 1999. „La psychanalyse et les femmes psychanalystes”. W Les femmes dans l'histoire de la psychanalyse, red. Sophie de Mijolla- Mellor. Bordeaux-Le-Bouscat: Esprit du Temps.

Deutsch Helena. 1944/1945. The Psychology of Women. New York: Grunne and Stratton.

Deutsch Helena. 2008. Konfrontacja z. sama sobq: Epilog. Tłum. Adam Pluszka. Warszawa: Cyklady.

Deutsch, Helena. 2016a. „O homoseksualizmie kobiecym”. Tłum. Mateusz Franczak. W Psychoanaliza w Polsce 1909-1946, red. Lena Magnone. Warszawa: Kronos.

Deutsch Helena. 2016b. „Osobowość »jak gdyby«”. Tłum. Mateusz Franczak. W Psychoanaliza w Polsce 1909-1946, red. Lena Magnone. Warszawa: Kronos.

Deutsch, Helena. 2016c. „Psychologia kobiet w odniesieniu do funkcji prokreacji”. Tłum. Mateusz Franczak. W Psychoanaliza w Polsce 1909-1946, red. Lena Magnone. Warszawa: Kronos.

Ferenczi, Sándor. 1924. Versuch einer Genitaltheorie. Wien-Leipzig: Internationaler Psychoanalytischer Verlag.

Freud, Sigmund i Josef Breuer. 2008. Studia nad histeria. Tłum. Robert Reszke. Warszawa: Wydawnictwo KR.

Freud, Sigmund. 2009a. Pisma społeczne. Tłum. Robert Reszke. Warszawa: Wydawnictwo KR. Freud, Sigmund. 2009b. Życie seksualne. Tłum. Robert Reszke. Warszawa: Wydawnictwo KR.

Friedan, Betty. 2012. Mistyka kobiecości. Tłum. Agnieszka Grzybek. Warszawa: Wydawnictwo Czarna Owca.

Gilman, Sander L. 1993. Freud, Race, and Gender. Princeton: Princeton University Press.

Gilmore Leigh. 1994. Autobiographics: The Feminist Theory of Women's Self-Representation. Ithaca London: Cornell University Press.

Magnone, Lena. 2016a. Emisariusze Freuda: Transfer kulturowy psychoanalizy do polskich sfer inteligenckich przed drugq wojna swiatowa. Kraków: Universitas.

Magnone, Lena 2016b. „Psychoanaliza w Polsce?”. W Psychoanaliza w Polsce 1909-1946, red. Lena Magnone. Warszawa: Kronos.

Malabou, Catherine. 1996. L'Avenir de Hegel: Plasticité, temporalité, dialectique. Paris: Libr. Philosophique J. Vrin.

Malabou, Catherine. 2004. Que faire de notre cerveau. Paris: Bayard.

Malabou, Catherine. 2007. Les nouveaux blessés: De Freud à neurologie. Penser le traumatisme contemporains. Paris: PUF.

Malabou, Catherine. 2016a. „Plastyczność a cierpienie mózgowe i psychiczne”. Tłum. Mateusz Burzyk. Znak 731. http://www.miesiecznik.znak.com.pl/to-samo-jest-rozne/.

Malabou, Catherine. 2016b. „To samo jest różne”. Tłum. Piotr Sawczyński. Znak 731. http://www.miesiecznik.znak.com.pl/to-samo-jest-rozne/.

Malabou, Catherine. 2017. Ontologia prazpadłości: Esej o plastyczności destrukcyjnej. Tłum. Piotr Skalski. Warszawa: Fundacja Augusta hr. Cieszkowskiego. 
Mitchel, Juliette. 1973. Psychoanalysis and Feminism: Freud, Reich, Laing and Women. New York: Vintage Books.

Mühlleitner, Elke. 1999. „Les femmes et le mouvement psychanalytique à Vienne”. W Les femmes dans l'bistoire de la psychanalyse, red. Sophie de Mijolla- Mellor. Bordeaux-LeBouscat: Esprit du Temps.

Mühlleitner, Elke i Johannes Reichymayr. 1997. „Following Freud in Vienna: The Psychological Wednesday Society and the Viennese Psychoanalytical Society 1902 1938". International Forum of Psychoanalysis 6: 73-102.

Rank, Beata. 2016. „Rola kobiety w ewolucji społeczeństwa”. Tłum. Mateusz Franczak. W Psychoanaliza w Polsce 1909-1946, red. Lena Magnone. Warszawa: Kronos.

Schorske, Carl E. 1980. Fin-de-Siècle Vienna: Politics and Culture. New York: Knopf. 
Agnieszka Więckiewicz - studentka kulturoznawstwa w Instytucie Kultury Polskiej na Uniwersytecie Warszawskim; członkini Collegium Invisibile. Publikowała w czasopismach naukowych, między innymi w: „Tekstualiach”, „Widoku. Teoriach i praktykach kultury wizualnej”, „Praktyce Teoretycznej”, „Polisemii”, „Zeszytach Filozoficznych AJD”, „Judaiście” oraz w tomach zbiorowych. Członkini zarządu Polskiego Towarzystwa Genderowego im. Marii Skłodowskiej-Curie i Mikołaja Kopernika; założycielka i przewodnicząca inicjatywy feministycznej „Sekcja Feministyczna” działającej w Instytucie Kultury Polskiej. Interesuje się historią ruchu psychoanalitycznego oraz teoriami psychoanalitycznymi. Przygotowuje pracę magisterską poświęconą obrazom czarności i rasy w imaginarium kultury niemieckiej pierwszej połowy dwudziestego wieku. Stypendystka ministra nauki i szkolnictwa wyższego za wybitne osiąnięcia naukowe.

\section{DANE ADRESOWE:}

Instytut Kultury Polskiej

Wydział Polonistyki UW

ul. Krakowskie Przedmieście 26/28

00-927 Warszawa

EMAIL: agnieszka.wieckiewicz@gmail.com

CYTOWANIE: Więckiewicz, Agnieszka. 2018. „Ontologia przypadłości »jak gdyby« w teorii Heleny Deutsch: Narodziny teorii kobiet albo sondowanie granic psychoanalizy.“ Praktyka Teoretyczna 2(28): 138-160.

DOI: $10.14746 /$ prt.2018.2.7

\section{AUTHOR: Agnieszka Więckiewicz}

TITLE: Ontology of ,as if' Identification in Helene Deutsch's Theory: The Birth of Women's Theory or Probing the Psychoanalytical Borders

ABSTRACT: The article presents a new interpretation of works written by Helene Deutsch, Polish psychoanalyst, one of the closest colleagues of Sigmund Freud and the precursor of women's psychoanalysis. Beginning with the social and cultural history of psychoanalysis, I try to (re)argue and (re)read the works of female analysts in Freud's movement, especially those by Deutsch. In the article I propose the unfamiliar and new possibility of studying and writing about women's psychoanalysis. One approach to the work of Polish analysts is to understand it not only as a clinical theory but also as a literature and philosophy. Working on a famous theory of ,as if' identification, developed by Deutsch, in the light of 
the concept of plasticity proposed by French philosopher Catherine Malabou, the article is a contribution to a new method in reading and understanding theory as well as non-clinical works by Polish analysts through the categories of identity, memory and plasticity.

KEYWORDS: psychoanalysis, plasticity, Deutsch, Malabou, self-analysis. 